\title{
Mass Media Internships in Vocational Training of Students Majoring in Journalism
}

\author{
Nataliia A. Tsymbal, Nataliia M. Savchuk, Valentina I. Avramenko, \\ Svitlana A. Sichkar and Iryna A. Denysiuk \\ Pavlo Tychyna Uman State Pedagogical University, Uman, Ukraine \\ https://orcid.org/0000-0002-1223-8476 \\ https:// orcid.org/0000-0002-8835-3921 \\ https://orcid.org/0000-0003-4859-041X \\ https://orcid.org/0000-0001-6262-2831 \\ https://orcid.org/0000-0001-8641-3444
}

\begin{abstract}
The purpose of this research was to answer the questions of how and to what extend the internship programme, seen as a part of their vocational training, could contribute to students' learning process and professional growth and how the students perceived the internship programme. This was a quasi-experimental study utilising quantitative and qualitative methods. Such statistical tools as a cumulative grade point average, the career motivation test, and Mettl's aptitude online test for journalists, the semi-structured interview for the focus-group, and references from internship host company were used for calculations of the variables. The dependence of variables on the internship was analysed using a two-way ANOVA. The study found that mass media internships significantly improve vocational training system of students majoring in Journalism. Due to involvement in this programme, students' academic performance and career motivation increased, journalism skills developed and the quality of this education rose. This internship programme fosters students' job-related skills like working in a team and fast-paced environment, time-management, editing and publishing, communication, and social networking, using software to create digital and printed content. This study implies that universitybased journalism education is likely to soon become a secondary process. This study implies and experimentally proves that universitybased journalism education should soon become a secondary thing as de-institutionalised education is emerging laying the basics for "entrepreneurial journalism".
\end{abstract}

Keywords: journalism; mass media internships; vocational training; tertiary students; quasi-experiment 


\section{Introduction}

Mass media internships (MMI) bridges the gap between vocational training of tertiary students majoring in journalism and their job realities which gradually enhances MMI's reputation for bringing benefits to both journalism students, as they experience their future professional role (GraduateJobs, 2018; Maben \& Edwards, 2015), and employers, as they gain access to the pool of 'up-andcoming' talent (Ismail, 2018; Ojomo, 2015). The challenges that the students are facing when applying or doing internships in Ukraine are a limited number of companies that can host the students, a limited number of the employees who are willing to supervise the student interns, the copyright issues related to the publications made by interns and their supervisors cooperatively, and students' digital awareness of using new media technologies (Dovzhenko, 2018).

However, these challenges are overweighed by the benefits internships provide. According to the study completed for the Committee on Employment and Social Affairs (EMPL) (Broek, Hogarth, Baltina \& Lombardi, 2017) on apprenticeships, internships, and volunteering which is in line with the Communication Department at George Mason University (Internships and Careers, n.d.), the internships provide triangular benefits the student, the training institution and the employer. Moreover, internships are to meet the challenges of global journalism education in the $21^{\text {st }}$ century (Goodman \& Steyn, 2017; Hurst, Thye \& Wise, 2014).

\section{Literature review}

There is a strong trend in developing a more critical journalist or reporter that can adjust to a rapid technological change (Donsbach, 2015; Josephi, 2019; Keel, 2019). However, it is emphasised that conventional training in Journalism still lacks provision for the students with hands-on experience. It is considered to be insufficient in enabling students to learn in an appropriately equipped environment that addresses the deficiencies in the current training system (Breit, 2018; Valencia-Forrester, 2020). Internship programmes, either paid or unpaid, strengthen journalism education with what is missing in current vocational training of the journalists-to-be (Gessesse, 2020; Reed, Walsh-Childers, Fischer \& Davie, 2020). According to the survey conducted amongst journalism and communication college graduates by Rosenstiel et. al. (2015), the internships were rated fifth (out of 12) important learning after self-study, tutoring, mentoring, and specialism-related courses. According to Goodman (2020), the internship programmes are the ways to provide students with both experiential learning and early job placement experience in journalism (Goodman, 2020; Goodman \& Steyn, 2017). Gillmor (2016) claims that the intern students who can work with the relative autonomy are of value as they fit into the company's costeffectiveness policy. Senat, Ketterer and McGuire (2019) suggested that internship programmes bring benefits to three parties: students, host company, and training institution that helps to improve the reputation of the latter. Previous studies have also reported that the curricula of institutions were not fully aligned with the demands and trends in the job market and industry (Goodman \& Steyn, 2017; Josephi, 2019; Senat et. al., 2019). 
The literature review found that internship programmes correlate with convergent journalism (Killebrew, 2002) based on the technology-mediated methods of delivery information. It brought a shift in journalism educational paradigm. Additionally, the above concept met the journalism job market demand in an employee with certain knowledge and personality profile who skilfully use different outlets to deliver news or stories. It was found that paid journalism internships have been a common practice in the European and American universities, but those programmes are still of a limited offer in Ukraine. For example, we found just nine media-related unpaid and paid internships for undergraduates in Ukraine in 2019-2020 (Studway Opportunities, n.d.) The Media Mobility Hub offers 15-day tuition fee-free internship for student-journalists in the editorial offices of the leading media in Kyiv. The participants of the journalism internship are supposed to master their skills in the production of information products for convergent newsrooms, radio, TV, social networks, and the theoretical foundations of the work of a modern universal journalist. The VoxUkraine offers an unpaid internship with a further employment opportunity to the students. They are supposed to specify trends and stories in data, work with Python, pandas, BeautifulSoup, Highcharts, be skilled in infographics (visualisation) and fluent in spoken and written English. The above suggests that the requirements are quite tough.

Given the above, the benefits of the internships seem to be admittedly obvious. Nevertheless, the literature review found a limited number of sources in both international and Ukrainian databases revealing assessment approaches of the practice of student engagement, mentoring, and student and programme effectiveness which created a gap for this study. Thus, the research questions were:

1) How and to what extent could the internship programme, seen as a part of their vocational training, contribute to students' learning process and professional growth?

2) How did the students perceive the internship programme?

The hypotheses for this study were:

$\mathrm{H}_{0}$ : There is no dependence of academic performance, career motivation, and journalism skills development on the participation of the students in the internship programme.

$\mathrm{H}_{1}$ : There is the dependence of academic performance, career motivation, and journalism skills development on the participation of the students in the internship programme.

\section{Methods}

This study utilised both quantitative and qualitative research instruments to answer the research questions (Trigueros, Juan \& Sandoval, 2017). The quantitative method tools like records of students' grades presented through the calculated Cumulative Grade Point Average (CGPA), the results of diagnostics of a career motivation (CMT), and Journalism skills online test to assess the basic verbal and quantitative aptitude of journalists were given the priority. The qualitative research instruments like the focus-group semi-structured interview 
and secondary data like references from internship host company were used to have an in-depth picture of the effectiveness of mass media internships (Zohrabi, 2013). The above were employed to control over the variables which were consolidated academic grades of sampled students, career motivation and perception of this approach to their vocational training boosted with the mass media internship programme. The experiment was followed by numerical and qualitative data analysis to validate the statistical significance of the experiment outcomes.

\subsection{Research Design}

This was a quasi-experimental study. It used mixed methods and convergent design (Creswell, 2014). The study completed in November 2019 and lasted half a year (Thyer, 2012). This study comprised three stages like a preparatory, experimental, and post-experimental (data analyses and interpretation) stage. The first stage was intended to examine the literature and best practices, sign agreements with the potential host company and design the internship guide for the host company and get it approved by the Board of Academics for Kyiv National University of Culture and Arts. At the experimental stage, sampling was performed, mentors were appointed, induction courses were delivered, the internship programmes were launched, run, and supervised. Here, the experimental group students received internship-based training, and the control group students were trained traditionally at a "Journalist's Lab" at university. After the above, the focus group interview was conducted, the data were processed and analysed followed by conclusions made (see Figure 1).

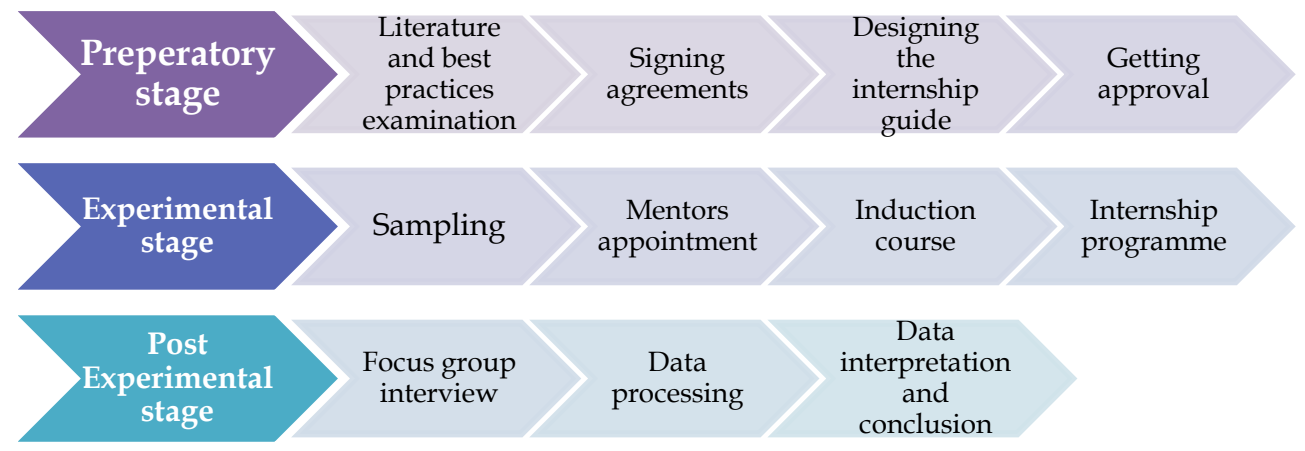

Figure 1: Visualised research design

Source: designed by the authors

3.2. A brief outline of the unpaid Internship Programme run at Media Holding "Media Group, Ukraine" Host Company

This was a 30-day part-time or flexible schedule programme. It was aimed at involving the student interns in assisting and performing typical tasks related to broadcast/digital news production, assisting (or 'shadowing') in the on-going projects, scriptwriting and editing video for a newscast.

Objectives: to foster students' job-related skills like working in a team and fastpaced environment, time-management, editing and publishing, communication, and social networking, using software to create digital and printed content.

Assessment: a two-part assessment of a supervisor and a mentor was supposed to be performed. 


\subsection{Sample}

A two-stage cluster sampling approach was used as it was possible to consider the students obtaining education in the same field of specialism were mutually homogeneous (Levy \& Lemeshow, 2011). At the first stage, 53 students of two groups in their third year of study seeking the Bachelor's degree in Journalism at Kyiv National University of Culture and Arts were purposefully sampled for this experiment. The above students formed the experimental and control groups. At the second stage of sampling, Cumulative Grade Point Average (CGPA) based academic grades (The European Credit Transfer and Accumulation System (ECTS)) of sampled students distributed on the 5-point scale (from 1 to 5) was calculated, and a career motivation test was administered. The experimental group (EG) involved 26 students (14 females and 12 males aged between 20 and 22) and the control group (CG) comprised 27 students (11 females and 16 males aged between 20 and 22). The CGPA scores, Mettl's Aptitude Test for Journalists (MATJ), and the results of a Career Motivation Test (CMT) are presented in the table 1.

Table 1: The CGPA scores (based on a 5-point scale), MATJ scores and the results of a CMT for EG and GE before the experiment

\begin{tabular}{|l|l|l|l|c|c|c|c|}
\hline \multirow{2}{*}{ Group } & \multirow{2}{*}{ CGPA } & \multirow{2}{*}{ CMT } & \multirow{2}{*}{ MATJ } & \multirow{2}{*}{$\boldsymbol{M}$} & \multirow{2}{*}{$\boldsymbol{S D}$} & \multicolumn{2}{|c|}{ Variances } \\
\cline { 1 - 4 } & & & & & & Subtraction & $\boldsymbol{p}$ - value \\
\hline$C G, n=26$ & 3.91 & 3.34 & 3.47 & 3.5733 & 1.14821 & \multirow{2}{*}{0.092} & 0.821 \\
\hline
\end{tabular}

Note: $M$ - arithmetic mean; $S D$ - standard deviations.

As can be seen, both groups might be regarded homogeneous according to the figures in the table and students' demographic features like age and year of study. They had approximately the same academic grades, the level of career motivation $(E G=3.34$ and $C G=3.31)$, and journalism skills $(E G=3.47$ and $C G=$ 3.61). Eleven students from the EG were randomly selected to be interviewed as the focus group.

\subsection{Instruments}

This study relies on Cumulative Grade Point Average (CGPA), Career Motivation Test (CMT) (PsychTests, n./d.), Mettl's Aptitude Online Test for Journalists (Mettl, n./d.), semi-structured interview for the focus-group and references from the internship host company. The dependence of variables on the internship was analysed using a two-way ANOVA. Career Motivation Test (CMT) comprises 102 questions that are supposed to be answered within 20 min. The test covers the topics as follows: achievements, structure and order, ambitions, responsibility, mobility, power, recognition, work-environment. Three experts proved the criterion validity, construct validity, and face validity of the test. Mettl's Aptitude Online Test for Journalists has three major sections as follows: verbal ability, logical reasoning, and quantitative aptitude. The test lasts 60 minutes. It comprises 60 multiple-choice items that cover the topics such as formal logic, seating arrangements, syllogism, deduction, analogies, number matrices, language coding, data sufficiency, statistics and probability, combinatorics, work rate, travel, polynomials, reading comprehension, 
grammar, writing skills, vocabulary, spelling. Three experts proved the criterion validity, construct validity, and face validity of the test.

\subsection{Semi-structured Interview Questions for the Focus-group Students}

It included 5 open-ended questions to comply with a stage-wise questioning approach that relies on such questions as opening, introductory, transition, core and ending. The semi-structured interview was conducted as recommended by Adams (2015). The EG respondents were randomly selected for the interview. To deal with the biasing effect, the Alumni Association members were hired to conduct the interviews. This was followed up by instructing. The informed consent was obtained from the interviewees. The interviews were recorded and transcribed. The answers were rated. The coding procedure was performed. The consolidated data was analysed using IBM SPSS Statistics software. The probability value of $\leq 0.05$ was considered significant.

1. How would you describe your impressions of (participation) in the internship programme?

2. What exactly caused you to think positively or negatively about the programme?

3. Was the course useful for your career as a journalist? Suggest your reasoning.

4. Would you become a referee for this programme? Why?

5. What, do you think, could improve this programme? Suggest your reasoning.

The responses of the focus group participants were processed in accordance with the guidelines for the focus group research (Onwuegbuzie, Dickinson, Leech \& Zora, 2009).

\section{Results}

Quantitative data were drawn for the measurement based on Cumulative Grade Point Average (CGPA), Career Motivation Test (CMT), and Mettl's Aptitude Online Test for Journalists. The qualitative data were obtained from the interview.

\subsection{Quantitative results}

Both tangible and intangible improvements in the EG and CG students could be observed and identified after the data collected had been processed. However, the dynamics of improvements in academic performance, journalism skills, and career motivation were greater in the students of the EG. Thus, the EG group students showed better results in the CGPA and a career motivation that had been administered in both groups (see Table 2). This was due to participation in the above internship programme run at Media Holding "Media Group, Ukraine" Host Company.

Table 2: The CGPA scores (based on a 5-point scale), MATJ scores and the results of a CMT for EG and GE after the experiment

\begin{tabular}{|l|l|l|l|c|c|c|c|}
\hline \multirow{2}{*}{ Group } & \multirow{2}{*}{ CGPA } & \multirow{2}{*}{ CMT } & \multirow{2}{*}{ MATJ } & \multirow{2}{*}{$\boldsymbol{M}$} & \multirow{2}{*}{$\boldsymbol{S D}$} & \multicolumn{2}{|c|}{ Variances } \\
\cline { 1 - 1 } & & & & & & Subtraction & $\boldsymbol{p}$-value \\
\hline CG, $n=26$ & 4.61 & 4.22 & 4.32 & 4.3833 & 1.22112 & \multirow{2}{*}{0.086} & \multirow{2}{*}{0.779} \\
\hline
\end{tabular}

Note: $M$ - arithmetic mean; $S D$ - standard deviations. 
A two-way ANOVA was used to define whether the above improvements were due to the students' participation in the internship programme (see Table 3).

Table 3: Two-way ANOVA results to define the dependence of academic performance and career motivation on the participation of the EG students in the internship programme

\begin{tabular}{|c|c|c|c|c|c|c|c|}
\hline Variance Source & $S S$ & $d f$ & $M S$ & F-value & $p$ & $\eta 2$ & $\boldsymbol{n}$ \\
\hline $\begin{array}{l}\text { Between groups } \\
\text { Group (Experimental/control) } \\
\text { Error }\end{array}$ & $\begin{array}{l}22103.31 \\
32.44 \\
21896.39 \\
\end{array}$ & $\begin{array}{l}3 \\
1 \\
57 \\
\end{array}$ & $\begin{array}{l}31.67 \\
434.34\end{array}$ & .079 & .769 & 0.001 & 53 \\
\hline $\begin{array}{l}\text { Inside groups } \\
\text { Estimated parameters /Before- } \\
\text { /After-the experiment) } \\
\text { Group*Parameter } \\
\text { Error } \\
\text { Total }\end{array}$ & $\begin{array}{l}11991.63 \\
1.19 \\
191.34 \\
11001.01 \\
21112.03 \\
\end{array}$ & $\begin{array}{l}64 \\
1 \\
1 \\
53 \\
121\end{array}$ & $\begin{array}{l}10.36 \\
157.27 \\
163.167\end{array}$ & .049 & .778 & $\begin{array}{l}0.001 \\
0.021\end{array}$ & 53 \\
\hline
\end{tabular}

Note: SS - total mean square error; df- degrees of freedom; MS - mean square; F-value; $\eta 2$ - mutual coupling factor; $\mathrm{p}>.05 ; \mathrm{n}$ - number of students.

The statistically significant difference in the Estimated parameters (Before/ After-the experiment) with a figure of .778 and group*Parameter (.391) can be seen in Table 3 which suggests that there is the dependence of improvements in the students' grades, journalism skills and their career motivation on the participation of the EG students in the internship programme.

The relation between the internship-based training of the EG and traditional training of the students of the CG at a "Journalist's Lab" at university was established through the descriptive statistics (see Table 4).

Table 4: Relationship between the internship-based training of the EG and traditional training of the students of the CG at a "Journalist's Lab" at university

\begin{tabular}{|c|c|c|c|}
\hline Variables & 1 & 2 & 3 \\
\hline 1. Academic performance & 1.12 & & \\
\hline 2. Journalism skills & $.47^{*}$ & 1.12 & \\
\hline 3. Career motivation & $.69^{*}$ & $.46^{*}$ & 1.12 \\
\hline Mean (Likert scale) & $69.43(4.12)$ & $128.12(4.78)$ & $16.77(4.11)$ \\
\hline Standard deviations & 10.32 & 23.87 & 4.09 \\
\hline
\end{tabular}

${ }^{*} p>.05$.

The figures for students' academic performance, journalism skills, and career motivation are positively and significantly correlated as they can be seen in Table 4 . The academic performance positively correlates with journalism skills $(r=.47 ; p>.05)$, academic performance well correlates with a career motivation $(r=.69 ; p>.05)$, and journalism skills positively correlate with a career motivation $(r=46 ; p>.05)$. As every correlation figure is positive, it suggests that the internship-based training is effective when used in vocational training of the students majoring in journalism. 


\subsection{Qualitative results}

Results of Semi-structured Interview Questions for the Focus-group Students ( $n=11)$

Question 1. How would you describe your impressions of (participation) in the internship programme?

Ten students responded that it was a fruitful experience. One student reported having her stereotypes broken. Those were about her future job like "lots of travelling within the country and abroad", "funny colleagues", "interesting topics", "objectivity of one's opinion".

Question 2. What exactly caused you to think positively or negatively about the programme? Eleven focus group students expressed positively about the programme. they proved that the programme met their professional needs, enhanced their professional credo, and improved their professional profile, became better at generating new ideas. Seven students confessed that they would do better in the programme if it was paid.

Question 3. Was the course useful for your career as a journalist? Suggest your reasoning.

Ten students agreed that the programme contributed to their professional background, challenged them in terms of deadlines, creativity, and being stressproof. Two students often felt the tasks impossible to manage to comply with requirements. The reasons for the above were a weak link between journalism education at university and a real job, and out-of-dated equipment used at university which prevented the students from acquiring up-to-date digital skills.

Question 4. Would you become a referee for this programme? Why? Eleven students agreed to advise this programme to their peers as it proved optimal for their future careers. The reasons for this were students' increased job motivation, enhanced networking contacts, progress in their studies.

Question 5. What, do you think, could improve this programme? Suggest your reasoning. Seven students found the programme too short and suggested prolonging it. Ten students responded that such a programme should be paid as a requirement for the experienced employees and the students are identical.

\section{Discussions}

To address the first research question, mass media internships proved to be the pedagogic booster for vocational training of tertiary students majoring in journalism. If introduced regularly, those internships could upgrade the journalism curriculum and raise the quality of journalism education. Additionally, it fitted each students' intellectual type, conceptual tempo, problem-solving, and learning styles. The latter is consistent with the findings of Valencia-Forrester (2020) who proved that equips a future journalist with necessary knowledge and skills so that the one could succeed in 'a dynamic media landscape'. This was due to the fact that the researcher sees internships as a work-integrated learning model. The results of this study supported findings of Gessesse (2020) and Reed, Walsh-Childers, Fischer and Davie (2020) who revealed that the internship programmes, either paid or unpaid, add much value 
to journalism education with such things as the integrated view of the occupation and learning from the very best. The study findings were in line with Steeves (2005) stating that (international) internships enhance the quality of journalism graduates. They engage the student in more in-field experience and specialised training in writing, reporting, photography, blogging, etc. They prepare graduates for tougher graduation requirements and job placement. According to Ojomo (2007), internships help graduates 'step out of the academic cocoon and into a professional arena'. They can apply their knowledge and skills and build up friendly in-field relationships. The results of the study fit the concept of convergent journalism produced by Killebrew (2002). It is referred to as the cooperation of the staff from print, broadcast, and online news who use recent technological advances to distribute content.

To address the second research question, the most illustrative students' responses about their perception of the intervention are presented below:

[...it was awesome and exhilarating to work with someone who inspires you by her/his own actions, way of approaching things, and professional lifestyle...]

[...the university training seems far behind the real job. The teachers just make us believe that we are on the track but we aren't... It is disappointing...]

[... I was so much willing to do my best in the projects that I hardly could sleep at night... I feel how rewarding this project was...]

The internships create a convergent journalism environment for the students to gain marketable cross-media skills like digital design, copywriting, and video or photojournalism. Though the programme was based on the increased cognitive and creative load, the students evaluated it positively and showed growth as both as a future staff member and a self-efficient personality. The programme made it possible to employ different extracurricular type contents, accelerate journalism skill formation, and increase learning effectiveness through more jobrelated tasks and assignments. The results supported the previous research conducted by Gillmor (2016). It draws attention to the fact that there is a need for journalists who are good at statistics, business, engineering/computer science, political science, law, design. There is also a need for journalists who can work with different computer programmes. The above scientist claims that the educational programmes accompanied by internships can satisfy those needs.

Though it was beyond the scope of this study, the programme reduced imbalance between the excessive teacher efforts in fostering writing and speaking skills in student journalists and teacher underperformance in fostering student digital skills which the focus group students reported while interviewed.

This paper makes several contributions to the theory and methodology of vocational training of the students majoring in journalism. First, this study adds to the theory and practice of journalism education. It boosted the research of Anderson, Glaisyer, Smith and Rothfeld (2011), Coombes (2019), Greenberg (2007) and Josephi (2016) who revealed the journalism education seen as a phenomenon. It enhanced the methodology of journalism teaching and training 
highlighted by Fourie (2005) and Harro-Loit and Ugur (2018). The study contributed to the theory of reflective practice in journalism education (Burns, 2004). It accelerated the introduction of media education and new technology in journalism education (Berkeley, 2009; Nkomo, Chidyagwayi \& Munikwa, 2016). It revealed the need for a shift to visual communication in the journalism curriculum (Blom \& Davenport, 2012). The study also added to best practice of journalism skills training (Larrondo Ureta \& Peña Fernández, 2018; Takahashi \& Parks, 2018). Secondly, the results of this study help better understand the importance of establishing a link between journalism education at university and a real job, upgrading university computer infrastructure, and doing internships at the host brick-and-mortar company but university lab.

\section{Conclusions}

Mass media internships significantly improve vocational training system of students majoring in Journalism. They contribute substantially to students' learning process and professional growth. Due to involvement in this programme, students' academic performance and career motivation increase, journalism skills develop, and the quality of this education rises. This internship programme fosters students' job-related skills like working in a team and fastpaced environment, time-management, editing and publishing, communication, and social networking, using software to create digital and printed content. The students perceive the internship programme positively. The reasons for students' positive perceptions of the programme were the increased job motivation, enhanced networking contacts, progress in their studies. This study implies that university-based journalism education is likely to soon become a secondary process. The interview suggests that the teachers should put greater effort into fostering student digital skills than training students' writing and speaking skills. Though the unpaid programme like this indirectly raises competition in the journalism job market, it raises the quality of the mass media product as a whole. The study had demonstrated the need for a shift to visual communication in the journalism curriculum. Further study is needed in the field of 'entrepreneurial journalism' theory and methodology.

\section{Recommendations}

Given the fact that the employees of the host company might behave hostile (unfriendly) to the students doing internships for the reason being that the students might be perceived as competitions, it would work if the students - as a separate team - were assigned to create some new project under the supervision of the experienced employee. Before launching the project, the staff might be involved in evaluating and providing feedback to that project. The internship programme would be more effective if it was run as a paid summer job. The student journalists could travel locally and internationally to collect news at the source. However, the Academic Board's special approval is needed because the summer time is considered to be extra-curriculum.

\section{Limitations and implications for the research}

It might be argued that it seems the limitation that the experiment was a singleinstitution experience with only one host company involved. Quasi- 
experimental research design and a number of variables studied were also limitations to this research. This study implies and experimentally proves that university-based journalism education should soon become a secondary thing as de-institutionalised education is emerging laying the basics for "entrepreneurial journalism". There might be stated that unpaid internships indirectly lead to the rise of the unemployment rate amongst qualified journalists.

\section{Acknowledgement}

We express gratitude to all people involved in the research and to Media Holding "Media Group, Ukraine" Host Company for their support in the research so that it ran smoothly.

\section{References}

Adams, W. (2015). Conducting semi-structured interviews. In K. Newcomer, H. Hatry, \& J. Wholey (Eds.), Handbook of Practical Program Evaluation (pp. 492-505). Hoboken, NJ: Jossey-Bass. https://doi.org/10.1002/9781119171386.ch19

Anderson, C. W., Glaisyer, T., Smith, J., \& Rothfeld, M. (2011). Shaping 21st-century journalism: Leveraging a "teaching hospital model" in journalism education. Washington, DC: New America Foundation.

Berkeley, L. (2009). Media education and new technology: A case study of major curriculum change within a university media degree. Journal of Media Practice, 10(2-3), 185-197. https://doi.org/10.1386/jmpr.10.2-3.185_1

Blom, R., \& Davenport, L. D. (2012). Searching for the core of journalism education: Program directors disagree on curriculum priorities. Journalism $\mathcal{E}$ Mass $\begin{array}{llll}\text { Communication } \quad \text { Educator, } & \text { 70-86. }\end{array}$ https://doi.org/10.1177/1077695811428885

Breit, R. (2018). Case-based education: A strategy for contextualising journalism curriculum in East Africa. Journalism. https://doi.org/10.1177/1464884918761629

Broek, S., Hogarth, T., Baltina, L., \& Lombardi, A. (2017). Skills development and employment: Apprenticeships, internships, and volunteering. Retrieved from https://www.europarl.europa.eu/RegData/etudes/STUD/2017/602056/IPOL _STU(2017)602056_EN.pdf

Burns, L. S. (2004). A reflective approach to teaching journalism. Art Design and Communication in Higher Education, 3(1), 5-16.

Coombes, R. (2019). Ten years of investigative journalism. BMJ, 367, 16892. https://doi.org/10.1136/bmj.16892

Creswell, J. W. (2014). Research design: qualitative, quantitative, and mixed methods approaches. Retrieved from http://fe.unj.ac.id/wpcontent/uploads/2019/08/Research-Design_Qualitative-Quantitative-andMixed-Methods-Approaches.pdf

Donsbach, W. (2015). Journalism and education [Streaming video]. SAGE Video. https:// doi.org/10.4135/9781473940161

Dovzhenko, O. (2018). Journalism education in Ukraine: does the system work? Detector Media. Retrieved from https://detector.media/doc/images/news/archive/2016/142347/DM_jouredu cation_2018-WEB-compressed.pdf

Fourie, P. (2005). Journalism teaching and training: Journalism studies: The need to think about journalists' thinking. Ecquid Novi African Journalism Studies, 26(2), 142-158. https://doi.org/10.3368/ajs.26.2.142 
Gillmor, D. (2016). Towards a new model for journalism education. Journalism Practice, 10(7), 815-819. https://doi.org/10.1080/17512786.2016.1164998

Gessesse, K. B. (2020). Mismatch between theory and practice? Perceptions of Ethiopian journalists towards applying journalism education in professional news production. African Journalism 1-16. https:// doi.org/10.1080/23743670.2020.1735470

Goodman, R. S. (2020). WJEC's Paris syndicate program: Discussions advance global journalism education. Journalism \& Mass Communication Educator, 75(1), 3-8. https://doi.org/10.1177/1077695820901940

Goodman, R. S., \& Steyn, E. S. (2017). Global Journalism Education in the 21st Century: Challenges and Innovations. Austin, TX: Knight Centre for Journalism in the Americas.

GraduateJobs. (2018). My Internship Experience in... Media with Jess Blackner. Retrieved from https://www.graduate-jobs.com/internships/media-internship-casestudy.jsp

Greenberg, S. (2007). Theory and practice in journalism education. Journal of Media Practice, 8(3), 289-303. https:// doi.org/10.1386/jmpr.8.3.289/1

Harro-Loit, H., \& Ugur, K. (2018). Training methods of listening-based journalistic questioning. Journalism Practice, 12(7), 918-934. https:// doi.org/10.1080/17512786.2017.1356687

Hurst, J. H., Thye, A., \& Wise, C. L. (2014). Internships: The key to career preparation, professional development, and career advancement. Journal of Family $\mathcal{E}$ Consumer Sciences, 106(2), 58-62.

Internships and Careers. (n.d.). Information for Current Undergraduate Students. Retrieved from https://communication.gmu.edu/undergraduate/internships-careers

Ismail, Z. (2018). Benefits of Internships for Interns and Host Organisations. K4D Helpdesk Report. Birmingham, UK: University of Birmingham.

Josephi, B. (2016). Journalism education. In J. Nussbaum (Ed.), Communication: Oxford Research Encyclopedias. New York, NY: Oxford University Press USA. https://doi.org/10.1093/acrefore/9780190228613.013.92

Josephi, B. (2019). Journalism education. In K. Wahl-Jorgensen, \& T. Hanitzsch (Eds.), The Handbook of Journalism Studies (pp, 121-136). New York, NY: Routledge. https://doi.org/10.4324/9781315167497-4

Killebrew, K. C. (2004). Managing media convergence. Pathways to journalistic cooperation. Ames, IA: Blackwell

Keel, G. (2019). Switzerland: Free journalism education for free media. In E. Nowak (Ed.), Accreditation and Assessment of Journalism Education in Europe. Quality Evaluation and Stakeholder Influence (pp. 175-188). Baden-Baden, Germany: Nomos Verlag. https:// doi.org/10.5771/9783845293851-175

Larrondo U. A., \& Peña F. S. (2018). Keeping pace with journalism training in the age of social media and convergence: How worthwhile is it to teach online skills? Journalism, 19(6), 877-891. https://doi.org/10.1177/1464884917743174

Levy, P. S. \& Lemeshow, S. (2011). Two-stage cluster sampling: Clusters sampled with equal probability. In R. M. Groves, G. Kalton, J. N. K. Rao, N. Schwarz, \& C. Skinner (Eds.), Sampling of Populations: Methods and Applications (pp. 269-330). Hoboken, NJ: John Wiley \& Sons, Inc.

Maben, S. \& Edwards, J. (2015). Social media internships: A case study of a student-run social media institute. Teaching Journalism and Mass Communication, 5(1), 69-87.

Mettl. (n.d.). Mettl's Aptitude Online Test for Journalists: Make headlines with the best of the best with Mettl! Retrieved from https://mettl.com/en/test/aptitude-testjournalism/ 
Nkomo, T., Chidyagwayi, L., \& Munikwa, S. (2016). Journalism education in the digital era: How schools of journalism in Zimbabwe are adapting journalism education to the digital age. $\quad$ Retrieved from https://www.researchgate.net/publication/319354029_Journalism_Education_i n_the_Digital_Era_How_schools_of_journalism_in_Zimbabwe_are_adapting_jo urnalism_education_to_the_digital_age

Ojomo, O. (2007). Optimizing internships in mass communication training. Journal of Social Sciences and Humanities, 15(1), 49-60.

Ojomo, O. (2015). Journalism trainers and newspapers editors agree on the internship as a weak link in journalism training in Nigeria. International Journal of Humanities and Social Science, 5(4), 104-111.

Onwuegbuzie, A. J., Dickinson, W. B., Leech, N. L., \& Zora, A. G. (2009). A qualitative framework for collecting and analysing data in focus group research. International Journal of Qualitative Methods, 8(3), 1-21. https://doi.org/10.1177/160940690900800301

PsychTests. (n.d.). Career Motivation Test. Retrieved from https://testyourself.psychtests.com/testid/3153

Rosenstiel, T., Ivancin, M., Loker, K., Lacy, S., Sonderman, J., \& Yaeger, K. (2015). Journalism and communication grads' experiences with school, student media, and internships. $\quad$ Retrieved from https://www.americanpressinstitute.org/publications/reports/surveyresearch/api-journalists-survey/

Reed, K., Walsh-Childers, K., Fischer, K., \& Davie, B. (2020). Restoring Trust in Journalism: An Education Prescription. Journalism \& Mass Communication Educator, 75(1), 40-45. https://doi.org/10.1177/1077695820904192

Senat, J., Ketterer, S., \& McGuire, J. (2019). Between a Rock and a Hard Place: Attitudes and Practices of Mass Communication Programs Regarding Unpaid Student Internships. Journalism \& Mass Communication Educator. https://doi.org/10.1177/1077695819882565

Steeves, H. L. (2005). Experiencing international communication: An internship program in Ghana, West Africa. Journalism \& Mass Communication Educator, 60(4), 359-375. https://doi.org/10.1177/107769580506000405

$\begin{array}{llll}\text { Studway } & \text { Opportunities. } & \text { (n./d.). } & \text { Retrieved }\end{array}$ https://diem.studway.com.ua/cat/stazhuvannya/

Takahashi, B., \& Parks, P. (2018). Journalists and communicators' perceptions of their graduate training in environmental reporting: an application of knowledgebased journalism principles. Frontiers in Environmental Science, 5. https://doi.org/10.3389/fenvs.2017.00094

Thyer, B. A. (2012). Quasi-Experimental Research Designs. New York, NY: Oxford University Press.

Trigueros, R., Juan, M. \& Sandoval, F. (2017). Qualitative and Quantitative Research Instruments: Research tools. Retrieved from https://www.researchgate.net/publication/323014697_QUALITATIVE_AND_ QUANTITATIVE_RESEARCH_INSTRUMENTS_Research_tools

Valencia-Forrester, F. (2020). Models of work-integrated learning in journalism education. Journalism Studies, 21(5), 697-712, https://doi.org/10.1080/1461670X.2020.1719875

Zohrabi, M. (2013). Mixed method research: instruments, validity, reliability, and reporting findings. Theory \& Practice in Language Studies, 3(2), 254-262. 